\title{
The fishermen inhabiting the Xuande and Yongle Islands in Xisha Islands
}

\author{
Li Liu ${ }^{1,2}$
}

Received: 25 April 2021 / Accepted: 3 August 2021 / Published online: 27 August 2021

(c) The Author(s). 2021

\begin{abstract}
Hainan Island fishermen have been engaged in fishing in Nanhai Zhudao (the Nanhai Islands) since ancient times. From sailing to the emergence of motorboats, the South China Sea fishermen have experienced different seafaring eras. Fishermen who work and live on the islands and reefs also have experienced living on islands seasonally to long-term. This article uses the inhabiting fishermen groups of the Xuande and Yongle Islands in Xisha Qundao (the Xisha Islands) as examples to demonstrate the unique livelihoods of the fishermen and reveal their role in the use of marine ecology to achieve sustainable development.
\end{abstract}

Keywords Fishermen $\cdot$ Inhabit the islands $\cdot$ South China Sea $\cdot$ Xisha Islands

\section{Introduction}

The South China Sea is a traditional fishing ground for Chinese fishermen; Chinese fishermen have been engaged in fishing and hunting since ancient times. Yi Wu Zhi (异物志, An Account of Strange Things) published in the Eastern Han Dynasty records that there are marine products such as sea turtles and hawksbills in the South China Sea Islands (Yang 2009). In the Jin Dynasty, Pei Yuan's “Guangzhou Records" recorded the situation of Chinese fishermen fishing in Dongsha Qundao (the Dongsha Islands) (Yue 2007). Zheng Ziyue described in The Geography of the South China Sea Islands that Chinese fishermen "fished as a business in the South China Sea Islands and reefs, and they have been accustomed to the routine for hundreds of years" (1947). By the Ming and Qing dynasties, there were dozens

Li Liu

xiaosaibao121@163.com

1 School of Sociology and Anthropology, Sun Yat-Sen University, 510275 Guangzhou, China

2 Southern Marine Science and Engineering Guangdong Laboratory (Zhuhai), Zhuhai, China 
of two-masted or three-masted sailing boats from Hainan Island travelling to Xisha and Nansha Islands to fish every year (Lin and Fengbin 1988). When sailing, fishermen use the monsoon to travel to and from Hainan Island, the Nanhai Zhudao, Southeast Asia and other places. Islands and reefs are the connecting points for maritime navigation. Some fishermen will stay on the islands for fishing and hunting. Over time, the islands and reefs of the South China Sea have formed a unique group of fishermen inhabiting Nanhai Zhudao. The Island fishermen mainly come from Tanmen, Wenchang and other places of Hainan Island, southern China, especially Tanmen. After the mid-1950s, motor sailing ships began to be adopted along the coast of Hainan Island. After the 1980s, motorboats replaced motor sailing ships and sailing ended completely. With the innovation of ships, the resupply of fresh water, food and other materials to the islands and reefs have also been enhanced and fishermen's inhabiting the islands is less restricted by the seasonal changes of monsoon climate or material conditions. The Xisha Islands are closest to Hainan Island and are a must for fishermen to travel to the Nansha Islands. The Xisha Sea area has become the main area where fishermen live and work on the island.

The Xisha Islands, formerly known as "Thousand Miles Stone Ponds" (Chen et al. 2004), are 180 nautical miles from Hainan Island. There are 23 islands, 7 sandbars, and a total land area of about $10 \mathrm{~km}^{2}$. Xisha Islands and reefs are generally small in size and low in elevation. Except for the high sharp rocks in the East Island Atoll, which are volcanic rocks, the rest are coral islands. The islands are mostly composed of coral fragments and shellfish debris and some islands have no vegetation or soil. From living on the islands seasonally to living on them for decades, fishermen have gone through a long and arduous process. According to the geographical distribution of islands and reefs, fishermen divide the Xisha islands and reefs into two archipelagoes, east and west because the fishermen set off from Hainan Island, first to the east group, then to the west group. They used to refer to the seven islands and reefs of the eastern group as "the upper seven islands" or "Shang Zhi / The Upper Stand-Off" The eight islands and reefs of the Western Group were referred to as the "Lower Eight Islands" or "Xia Zhi / The Lower Stand-Off," collectively referred to as the "Upper Seven and Lower Eight Xisha Islands" (Ju 1954) and were later named the Xuande Islands and Yongle Islands respectively. ${ }^{1}$ The Xuande Islands are mainly composed of seven islands arranged in an arc, called Qilianyu. In the Qing Dynasty, Chen Lunjiong traveled to the South China Sea and wrote Hai Guo Wen Jian Lu (海国闻见录, Records of Things Seen and Heard about the Coastal Regions), calling the Xisha Islands the "Seven Cays Ocean" and writing, "The Seven Cays Ocean is in the southeast of Wanxian, ${ }^{2}$ Hainan Island, Guangdong, and everyone who goes to the South China Sea must pass through it. There are Changsha Shitang and other reefs in the

\footnotetext{
${ }^{1}$ In 1947, in order to commemorate the great achievements of Zheng $\mathrm{He}^{\prime}$ s seven voyages to the western seas between the Yongle and Xuande years of the Ming Dynasty, the Upper Seven Islands were named "Xuande Islands" and the Lower Eight Islands were named "Yongle Islands."

${ }^{2}$ Wanxian county is located in today's Wanning County, Hainan Province, China. The Seven Cays Ocean refers to this area in Xisha Qundao, which lies to the southeast of Wanning County, located between the southeast of Hainan Island and the reef in the dangerous area of Xisha Islands.
} 
northeast, so you should be cautious when sailing" (Chen and Li 1985). The eight islands and reefs of the Yongle Archipelago are distributed in a ring shape. Although the land area of each island and reef is small, there are reefs that are several times the area of the islands, possessing abundant marine products.

Fishermen now inhabiting islands in the South China Sea are mainly distributed on Yongxing Island and Zhaoshu Island in the Xuande Islands of Xishaq Islands, Jinqing Island, Yagong Island, Lingyang Reef (Antelope Reef), Yinyu and other islands in the Yongle Islands of Xishaq Islands. In addition, there are some fishermen living on the Meiji Reef of the Nansha Islands. The field study in this paper involves the islands and reefs inhabited by all fishermen in Xisha Islands. Fishermen living on islands in the South China Sea group together based on the relationship by consanguinity and region. Fishermen from the same place are often concentrated in several fixed islands and reefs. In addition, due to the differences in the geographical environment and ecological conditions of the islands and reefs, the islands and reefs are of different functions. Fishermen's inhabitation on different islands and reefs have a distinction between center and the affiliated. In this way, different sizes of communities of fishermen are scattered across the vast sea.

Regarding the study of fishermen in the South China Sea Islands, scholars of history, geography and archaeology have made important contributions. South China Sea history expert Han Zhenhua once visited and studied the Xisha Islands in 1977 (Kou and Guoqiang 1990) and compiled a collection of South China Sea historical materials (Han 1981). Historians Lin Jinzhi and Wu Fengbin also went to study the Xisha Islands in the 1970s (Lin 1981; Wu 1985). The geographer Ju Jiwu went to Nansha Islands in 1946 to study the names of the Nansha Islands, reefs and temples in the Nansha Islands and reefs (Ju 1954). In the early 1970s, Liu Nanwei went to the Xisha Islands, systematically studied the names of the South China Sea islands and reefs (Liu 1994; Liu 1996). Zeng Zhaoxuan participated in a field survey of the Xisha Islands in July 1981 (Zhao et al. 2016). In the 1990s, archaeologist Wang Hengjie went to the Xisha Islands several times for archaeological investigations (1992). Since the 1970s, Chinese archaeologists have conducted many archaeological excavations on the Tang and Song Dynasty relics on Ganquan Island and Yongle Islands. The objects unearthed at the site show that the fishermen on the island at that time had a considerable understanding of the water sources, topography, climate, and products of the Xisha Islands (Han et al. 1988).

As communities of fishermen on remote islands and reefs, their ways of livelihood are very distinctive. From the research of history and geography scholars, we can get a glimpse of the life and work of fishermen on the islands and reefs of the South China Sea. However, there have been few anthropological studies of these groups based on field study. Anthropologists' research on China's islands and fishing villages is mainly concentrated in offshore and inshore areas. For example, Wang Songxing's Wang, 1967 study of Guishan Island is a representative of early island ethnography (1967). The research of Liao Disheng and Zhang Zhaohe on the fishing village of Da'ao reveals the changes in the fishing village at the mouth of the Pearl River in the past two decades (2006). 


\section{Methods}

Based on anthropological field study and interviews, and from the marine standpoint and fishermen's perspective, this paper presents an overview of the life and work of inhabiting fishermen and a unique sample of the diversity of fishery livelihoods and island cultures in China. The ecological wisdom displayed by the fishermen living on the islands in their interactions with marine islands is also instructive in dealing with the many issues concerning the relationship between human and the sea and between human and nature today. As the main part of the population of Sansha City, the inhabiting fishermen are in a period of transformation in the development and construction of the South China Sea Islands and Reefs. This paper is of significance to promoting fishermen's participation in Sansha's community construction and the protection of marine ecological environments with their local knowledge and experience.

The article is based on two field works in the South China Sea. From July 26th to September 1st, 2018, and from April 15th to May 15th, 2019, the author conducted field work in the Xuande and Yongle Islands for more than 2 months. During the sea voyage, the author interviewed the captains, sailors and fishermen on the boat and conducted field work on the islands and reefs when close by. During the voyage, uninhabited islands, reefs and sandbars that are closely related to the livelihoods of fishermen, such as Huaguang Reef, Panshiyu, Langhua Reef, and Quanfu Island, were also visited.

\section{Discussion}

\section{Geographic and ecological cognition of the islands and reefs of the fishermen living on the island}

Sailing means "from one island to another" (Braudel 2014). In the early days, the fishing boats stayed on the islands and reefs when sailing through Xisha area, mostly for shelter from the wind and staying overnight. Fishermen used simple tools to pick up sea products in the surrounding shallows. These kinds of opportunistic fishing and hunting activities were not fixed on a certain island or reef. At that time, the fishermen mainly fished for fish and sea turtles, and collected sea cucumbers, shells, snails and oysters (Han et al. 1988). They brought seafood to Southeast Asia for sale, and then purchased cloth and other goods from Singapore and other places and then returned to Hainan Island.

Lao Ye, a fisherman living on Yagong Island in the Yongle Archipelago of Xisha Islands, told the story of his father's journey to Southeast Asia in his early years:

After the winter solstice, he took advantage of the northeast wind to pick up horseshoe snails and sea turtles in Xisha Islands and Nansha Islands and transported them to Singapore. In April of the next year, he returned from Singapore by the south wind and bought back towels, matches, cement, diesel, 
and wood (for building houses). Another year after the winter solstice, he departed by the northeast wind.

There are abundant seafood near the islands and reefs and the fishermen can harvest quite a lot in a relatively short period of time. Some fishermen choose to stay on the island, aiming for several kinds of seafood with high economic value and good marketability at a specific time. They dry the caught seafood and ship it to Southeast Asia for sale or take them back to Hainan Island for sale when ships return from Southeast Asia and other places. At this time, islands and reefs of the South China Sea are a seasonal production base for fishermen. The sailing is dangerous and far from home. Fishermen have built seasonal camps on some islands to improve their working and living conditions.

During navigation and livelihood activities that depend on islands and reefs, fishermen have gradually become familiar with their geographical and ecological conditions, the laws of tidal currents and have a good understanding of the distribution of seafood in the surrounding seas. Over a long time, the fishermen have mastered a rich and accurate set of local marine knowledge in the South China Sea. The prime example is the way that the fishermen named the islands and reefs in their Hainan dialect. To date, more than one hundred of the standard place names of the South China Sea Islands are based on "fishermen's place names." These place names are a classification system created by fishermen on the basis of their knowledge of the shapes, characteristics, and nearby seafood of the islands and reefs and on the basis of long-term marine practice (Liu, 2014).

Residing on the islands in Nanhai Zhudao for a long time is called "Zhanzhi," meaning that the South China Sea Islands and Reefs are used as a base for fishermen to live on to catch seafood. "Zhi" refers to islands and sandbars that are not submerged during high tide (Liu 1996). For example, the North Island of the Xuande Islands is called "Changzhi" because of its long terrain. Ganquan Island in Yongle Archipelago is called "Yuanzhi" by fishermen, because Ganquan Island is an oval island. Jinyin Island is called "Weizhi" because Jinyin Island is located at the outer end of Yongle Atoll. Atolls with lagoons in the middle are vividly and collectively referred to as "baskets" or "circles" by fishermen. The Big Basket, Second Basket, and Third Basket refer to the three major atolls outside the two island groups of Xisha Islands, Huaguang Reef, Yuzhuo Reef and Langhua Reef. Some islands, reefs and sandbars are named and classified by their products. The three sandbars in the Xuande Islands grow red purslane, and fishermen call them Red Grass One, Red Grass Two, and Red Grass Three in order from north to south. When naming the same type of islands and reefs, fishermen also use a combination of numbers to classify and distinguish. Due to the fact that they come from the most direct observation and experience of fishermen, these names are vivid and accurate. In addition to the geographical morphology and properties of islands and reefs, there are also some names that imply temporal and spatial information about fishermen's sea voyages. The old fishermen who lived on 
Zhaoshu Island explained that they called Zhaoshu Island Dark Ship Island because their boat set off from Tanmen and arrived at Zhaoshu Island when the sun just set and the boat landed in the evening. Zhongjian Island is called "Halfway" by fishermen because the voyage from Hainan Island to Nansha Islands area is halfway there. These kinds of names not only connect their place of departure and destination, but also define space through time, which promotes the fishermen's extensive and diverse connection and cognition of the surrounding environment.

Naming the islands and reefs means that the fishermen classified and coded the islands, reefs and sandbars of the South China Sea. Each name is appended with information about what it refers to, which is a manifestation of the fishermen's deep understanding of the South China Sea islands and reefs. It is because fishermen use the most familiar language and their own understanding to describe the islands and reefs, these place names can be passed down and used from generation to generation. The information in the names also enables fishermen to clarify their position in the sea and be able to cope with various changes. Those that are windsheltered, have fresh water, and have some kind of seafood, have place names that also indicate the function and value of the islands, reefs and sandbars, and fishermen will arrange their lives and work accordingly. The local marine information system reflected by place names is the basis for the livelihoods of fishermen living on the island.

To this day, about half of the more than 20 islands in Xisha Islands above the water are inhabited by fishermen. The number of fishermen living on some individual islands has exceeded 100. According to related research by Robin Dunbar, an anthropologist, if a group only relies on gathering, fishing and hunting, the number of people should be limited to 150. This is the highest number of people that can gather, live together, and cooperate effectively (Bauman 2013). The prerequisite for groups of this number is to have a land area with sufficient carrying capacity. The islands and reefs of Xisha Islands obviously do not have such geo-spatial conditions. In terms of the land area of islands and reefs in Xisha Islands, the North Island of the Xuande Islands has an area of $0.4 \mathrm{~km}^{2}$, and Zhaoshu Island has an area of $0.22 \mathrm{~km}^{2}$. The islands where fishermen live in Yinyu, Yagong Island, Lingyang Reef and other places in Yongle Islands are only $0.01 \mathrm{~km}^{2}$. This also determines the small scale of the fishermen habitations on the islands and reefs of the South China Sea. In the current fishermen habitations in the Xisha Islands, the number of fishermen varies from serveral people to more than a hundred. These numbers are based on the expected amount and type of seafood that individuals can catch in the surrounding waters. Once the catch is reduced, some people will withdraw and look for new places. In the long run, the islands and reefs will reach a dynamic balance of fishermen. It is also in this kind of operation that among the islands and reefs scattered in the South China Sea, a large number of fishermen have gathered on a few large islands and reefs that became the centers. Small fishermen habitations have formed on some small islands, and in this case the Xisha Islands have formed several communities of fishermen living on the islands. 


\section{Island life and livelihoods of the inhabiting fishermen}

\section{Obtaining shelter and food}

Living and feeding on a certain piece of land will make a person a part of that land, in essence (Sahlins 2003). From seasonal camping to long-term residence on the island, fishermen began to arrange their daily lives with islands and reefs as a unit. Fishermen make full use of the natural resources of the islands and reefs to build safe shelters. By the end of the twentieth century, several small habitations had formed on some islands and reefs in the South China Sea. For example, Zhaoshu Island and Yongxing Island in the Xuande Islands, Jinqing Island, Yagong Island, and Lingyang Reef in the Yongle Islands. The fishermen will take the following into account in order to inhabit the islands and reefs: the distribution of seafood around the islands and reefs, the impact of the tidal monsoon on the islands and reefs, and the resources on the islands. Some islands are rich in trees and vegetation, and some have only coral debris and not even a blade of grass grows. All these affect the daily life of fishermen living on the islands in the aspects of their residence and food, etc.

The islands are far away from the mainland and transportation difficulties have led to a shortage of resources on the islands. The structure and form of houses on the islands and reefs are derived from the raw materials available on the islands where the fishermen are located. The fishermen collect materials locally, using coral stones and shell remains as their main building materials. Their houses are called coral stone houses or coral houses. The coral stones that rise above the water surface at low tide around the islands are in layers and can be stripped off to build the main body of the house. Wood and cardboard that drifts from the sea can be used to build the roof. Driftwood is not easy to get, the fisherman said:

\section{"I was very happy to find a piece of wood when I went out to sea. I saw it} from a distance, (and I) stopped fishing."

Yagong Island in the Yongle Archipelago was unsuitable for building houses due to the geological conditions of the island, but fishermen still live in low-rise huts. These houses are walled with gray-brown coral stones and topped by the remains of the largest bivalve clam in the ocean, forming a unique landscape. The location and orientation of houses on the island takes into account the influence of monsoons, ocean currents, and waves on the islands. Therefore, the locations of the residences on each island must be the locations that are, after the integrated elements are considered, the safest and most convenient locations for going out to sea. Coral houses and wooden huts on each island have their own characteristics. Fishermen build shelters based on their own understanding of shelters and their respective needs. When building houses, they have to consider the storage and drying of fishing gear, catches, etc. As Tim Ingold pointed out, for these dwellers, houses are not just constructed, but created based on planning, with the owner's ideas and various choices (Ingold 2000). 
The houses completed by the fishermen according to their own wishes reflect the needs and aesthetics of the owners. Fishermen on Yagong Island build low wooden huts, located on the edge of the lagoon. The houses are topped with giant clamshells and coral stones and the windows have hand-made grilles and flaps to provide ventilation and consider the impact of typhoons. There is a coral stone house on Ganquan Island. The coral stones above and below its wall are of different colors. Because the owners of the house have been improving the house continuously for decades, the upper layer of the coral stone wall is newly built, which is dark. While the lower layers become lighter after more than 20 years of wind and sun exposure. The owner of the house is a couple. The husband built the house and lived on the island first, his wife went there 10 years later. The couple renovated the house together. This is very rare on Xisha islands. Usually brothers or father and son live on the island together. On the threshold of this coral house, the owner used small white shells to strikingly lay out four words: "Home on the island." These shelters connect the fishermen and the surrounding natural environment, making them a part of the entire marine island ecosystem. Due to the limitation of the size of construction materials, the area of coral stone houses is very small; usually five or six square meters. Typhoons occur frequently in the South China Sea. In order to prevent typhoon damage, coral stone houses are often built very low and concentrated on the flat terrain of the island, but they also face the danger of seawater intrusion by typhoon. In 2013, a super typhoon caused the sea to flow over Lingyang Reef, and the coral houses on the island were razed to the ground. After the typhoon, the fishermen rebuilt the coral houses. Fishermen who have mastered the skill of building houses and cooperation strategies have long been accustomed to this.

"The islands are alone in the sea. Fresh water, people and materials are rare" (Chen et al. 2004). As far as life on the island is concerned, in addition to the harsh natural environment, "fresh water is the most difficult thing to get" on the islands and reefs of the South China Sea. This is the deepest collective memory and feeling of the fishermen on the islands and reefs. Ganquan Island in the Yongle Archipelago is named for its freshwater wells. ${ }^{3}$ Ganquan Island has also become a place for the fishermen of nearby islands, reefs and fishing boats to obtain a supply of fresh water. In the past, from time-to-time fishermen on the Lingyang Reef and other islands and reefs would drive small boats with plastic buckets to Ganquan Island to fetch fresh water. The waves around Ganquan Island are so big that the process of taking water is often very difficult and dangerous. In addition, drinking water on the islands relies on fishing boats and purchase ships from Hainan Island. The early purchase ships and fishing boats only had a load of tens of tons, and the materials that could be used to aid the fishermen on the island and reefs were very limited. Moreover, the period of time for ships to travel to and from islands and

\footnotetext{
${ }_{3}^{3}$ Ganquan Island in Yongle Atoll has an area of $0.3 \mathrm{~km}^{2}$. In 1909, Li Zhun, Fleet Commander of Guangdong Province in Qing Dynasty, patrolled the sea and discovered that there were two freshwater wells in the lowlands of the central part of the island. The spring water was sweet and drinkable. He said: "(Someone) has obtained fresh water and tasted it, it is very sweet, and the digging of the ground is no more than $3.33 \mathrm{~m}$. I tasted it, and it really is very sweet. Then it is named Ganquan Island, with carving stone and hanging flags to commemorate it.” (Li zhun (李准). 1933. Li Zhun Xunhaiji (LI Zhun's marine inspection) (《李准巡海记》). Guowen Weekly Press (《国闻周报》). Vol. 10. No. 33: 1-8.) "Hence, Ganquan Island is named for this.
} 
reefs is long and there is no fixed time. Sometimes under the influence of tropical depressions and typhoons, fishing boats do not go out to sea and there is no supply on the islands for several months. In this case, the fishermen living on the islands have to collect and accumulate rainwater. They collect rainwater under the eaves, dig holes in the ground and cover them with canvases to collect rainwater, and collect fresh water in the depressions on the reefs of the islands.

The North Island of the Xuande Archipelago is located in the north of Yongxing Island, the main island of Xisha. The island is more than $1500 \mathrm{~m}$ long and $290 \mathrm{~m}$ wide. Hainan fishermen call it "Changzhi." Old He, a fisherman on the North Island, was born in 1952. Old He has lived on the island for more than 40 years. Every Spring Festival, other people return to Hainan Island, only Old He stays. He is accustomed to the peaceful and quiet life on the island and he wants to return to Xisha after at most 10 days on Hainan Island. The longest time he has spent on the island without leaving is 7 months in a row.

I came to the island in 1967. At that time, I came with a sailboat, the sailboat of the production team, with two sails, one in front and the other in back. I first lived on Bird Island ${ }^{4}$. I have lived on both Zhao Shu and Xishazhou Island. I have lived on North Island for the longest time, more than 30 years. Here on the North Island, I almost know where each stone is and where each marine product is. I know where to go to pick up certain kinds of snails. In the past, the most difficult thing on the island was not having fresh water, so I had to pick up a little bit of water on the reef and come back. I could only brush my teeth and take a bath with seawater.

Yinyu (Silver Island) is a small sandbar in the northeast of Yongle Atoll, with an altitude of $2 \mathrm{~m}$ and an area of $0.01 \mathrm{~km}^{2}$. Legend has it that a boat sank here in the late Qing Dynasty and fishermen picked up a large amount of silver ingots and called it "Silver Island." There are large reefs around Yinyu, which fishermen call Senping Beach. There is abundant seafood here, rich amounts of red mouth snails, grouper, redfin nakecheeked pory, etc., so small habitations with dozens of people have formed on the island. Compared with the Xuande Islands, it is more remote. Li, a fisherman who lives on the island, talks about their past life:

"Got water by rain, dug a hole in the ground to put a bucket in, covered the bucket with canvas, and dug a hole in the middle of the cloth to catch rainwater."

Yagong Island, also located in Yongle Atoll, is shaped like a duck and due to special geological reasons, the sandbar at the end of the island will "swing" due to the monsoon and is called "duck swimming" by fishermen. The low coral huts and wooden shacks on Yagong Island are gathered at the corner of the island. The

\footnotetext{
${ }^{4}$ The East Island of the Xisha Islands is the main habitat for birds such as white boobies and is called "Bird Island" by fishermen.
} 
fishermen collect rainwater under the eaves. A fisherman living on the island described their past life like this:

We used to put canvas on the eaves, put a bucket underneath, and draw the rain down when it rains. Salty water was always (used) for bathing. After washing in the sea, at most, a small spoonful of fresh water was used for the last wash. When there was a very short fresh water supply, there was not even one spoonful of water.

On the islands and reefs in Xisha Islands where fishermen live, there are several blue plastic buckets for storing water at the door of each fisherman's home, with a capacity of several tens to hundreds of jin (jin, a unit of weight, about $1 / 2 \mathrm{~kg}$ ), and the name of the owner is written on them. These blue plastic buckets have become eye-catching signs showing there are fishermen living there. The fishermen say that some people's fresh water has been preserved for half a year or even a year in case the supplies are cutting off during the typhoon. Fishermen have rich experience in island life and as long as they have fresh water, they can survive on isolated islands. There are more than ten typhoons passing through the Xisha sea area every year. In the face of typhoons, the fishermen on the island also have their own countermeasures. Liang, a fisherman from Zhaoshu Island, said:

Typhoon "Butterfly" hit here in 2013, and all the houses were gone. The houses are not so strong, you just cannot keep them intact. We put rice and fresh water in buckets, dig a hole in the ground, put them in and cover them. As long as there is water and rice, we have no problem to light and burn wood here. At least (we can go on) many days without starving to death. Everything else doesn't matter, as long as people are safe, our homes all can be rebuilt.

On flat ground behind the fishermen's village on Zhaoshu Island, there are still holes that are as deep and as big as their water-storing plastic buckets. The fishermen keep them for emergency use.

The islands lack terrestrial animals and flora. The islanders' food is mainly fish, snails and other seafood. In the early days, fishermen who went to the islands only dared to eat familiar types of seafood to avoid poisoning and other unexpected occurrences. Old He from North Island told us:

I used to be afraid of getting sick on the island, so I didn't dare to eat a lot of things. For example, although there are a lot of lobsters, I only ate small grouper because I was afraid of stomachache and there was no medicine on the island.

In the past, fishermen would bring enough food to the island, including dried vegetables, pickles, tea, beans, etc. Because there were very few things to grow on islands and reefs, beans brought could be made into bean sprouts, and bean sprouts 
could be used as vegetables. ${ }^{5}$ Pickles were easy to store. There are still dozens of dark brown clay pots stacked on Ganquan Island, which fishermen use to store pickles. When boats are coming, families also send dried vegetables and bacon from Hainan Island. Sometimes the boats that come to buy products (buy boats) also distribute some of their supplies to the fishermen on the islands, which is an unwritten rule in the South China Sea. The buy boats always come and go, while the islanders stay on the islands all year round. When a boat is to call on the island, it will give some of the ship's supplies to the fishermen on the island.

With the development and construction of the islands and reefs in the South China Sea, desalinated water is available on the island, which can be used for washing and irrigation. However, drinking water still has to be transported from Hainan Island. Vegetables and fruits can also be replenished by regular voyage supply ships. However, on the South China Sea islands and reefs with high temperature, high salt and strong ultraviolet rays, fruits and vegetables are difficult to preserve. Especially in the Yongle Islands, the frequency of supply ships is low. There is no soil to grow vegetables on the Lingyang Reef, Yinyu and other islands. Fish and snails are still the main food of the islanders.

The fishermen are engaged in mobile fishing and hunting activities, with the islands and reefs where they live as their base camp. The life of fishermen on islands and reefs is restricted to a specific space and they live close to each other. When not going to sea, the fishermen drink tea and chat in the open field. Occasionally, fishermen on nearby islands also drop in on small boats, have drinks and dinners, and exchange information. They cook seafood quickly and simply and pay attention to the original flavor. Some elderly people handle the freshly caught seafood in a more primitive way. For example, on Yagong Island, an old man burned a few pieces of firewood outdoors on the coral debris next to his house in the morning and cooked the octagonal snails and horseshoe snails he picked up early in the morning in a large pot. The firewood was burning and the snails were cooked in clean water. After opening the lid, he picked up the snails. He picked up a coral stone next to him and smashed the snail shells, took out the snail meat, and shared it to the people nearby. This recreates the scenes of island life and cooking of seafood of the ancestors who came to the islands in the early days.

\section{Livelihoods and skills}

The fishermen who live on the islands in the South China Sea refer to their main mode of production on the islands and reefs as "Xing Pan." "Xing" means walking in Chinese, here refers to walking on the reef flats, looking for and picking up seafood, and "Pan" is the coral reef flat surrounding the island. Although the area of the islands and reefs in the South China Sea is small, the reef flats surrounding the islands and reefs are several to dozens of times the area of the islands. Coral reefs are the home base of marine animals. "Any place where coral reefs are distributed is a good place for fishing" (Ju 1954). There are various microorganisms in coral cavities. Sea stars, sea urchins, crinoids and other mollusks live in the cracks of the

\footnotetext{
${ }^{5}$ Here, I referred to the relevant information given by the anonymous reviewer. Thank you very much.
} 
coral bushes. These will attract sea prawns and fish to move around and prey, and larger fish will follow. In the early days, island-resident fishermen walked on reef flats, collecting snails, shellfish, sea cucumbers and other seafood with high economic value. Although there is a deep sea outside the reef, the water depth on the reef is only two chi (chi, a unit of length, about $1 / 3 \mathrm{~m}$ ) at low tide, even small boats with very shallow draft cannot drive on it. The fishermen would tie a rope around their waists with one end of the rope tied to a plastic basket surrounded by foam as a float. They walked on the reef flat and put the seafood they picked into the basket. The reefs have depths and shallows. According to the situation, they had to walk to pick up seafood or snorkel from time to time to catch the seafood in the water. On the periphery of the reef, at the junction with the deep water area, there can be layers of waves, and an area of blue, still water called the glass sea on the reef is inlaid with white waves. From a distance, the scene of fishermen catching seafood is walking in a circle of waves. Therefore, the livelihood of fishermen working on reef flats is also called "walking on the waves," which is the main operation method for fishermen living on islands.

The operation method of "Xing Pan" stems from the fact that the reef flats are very rich in seafood and fishermen do not have to venture farther, and can pick up enough seafood just on the reef flats. With the increase of fishermen living on the islands, the resources near the islands and reefs have decreased, and the scope of fishermen's operations has extended to the surrounding waters. They have accumulated rich experience in offshore operations and are very familiar with the weather, the changes in the color of the sea, and the activities of marine animals. In day-to-day island practice, fishermen have summed up various laws and applied them to their daily work.

Yongxing Island is the main island of Xisha Islands and one of the earliest islands where fishermen began living. The fisherman Lao Zheng who resides on the island was born in 1962 in Yelin, the eastern suburb of Wenchang, Hainan. He has an 8-m-long, 60-hp boat. Old Zheng goes to sea with his son. They go out to sea at 8 o'clock in the morning and return to the island at 4:30 in the afternoon. On the afternoon of April 17, 2019, Old Zheng came back from the sea and sat in front of his house. On this day, he picked up more than 10 jin $(5 \mathrm{~kg})$ of snails and caught more than 10 jin $(5 \mathrm{~kg})$ of small groupers:

I have lived here on the island for 32 years. I mainly fish, fishing for mackerel and grouper. I catch fish mainly on the edge of the island, diving 1 to 3 meters and throwing hooks. Fishing for groupers requires octagonal fish as bait. If you catch mackerel, you need shellfish or mackerel skin as bait. I know every stone in Xisha, where there are fish, when they come, and I know where to go to catch them. The mackerel are at the head of Zhaoshu Island, the tail of Yongxing Island, and Nanshazhou. There are many octagonal fish at Nanshazhou and Zhaoshu Island. Now we are catching small octagonal fish, redfin nakecheeked pory, grouper, and stone fish. The redfin nakecheeked pory come up at this time in April and May. In June there will be less redfin nakecheeked pory. There are more stone fish in March. Octagonal fish, cuttlefish, and mackerel come here in the same month and the same season, but there won't be any more in March. There are snails and groupers at all times. 
As he spoke, he got up and showed the big hook for mackerel fishing. The hook had been bitten open, indicating the ferocity of this kind of fish. At first, he followed the elder generation on the boat and the elders took him out to the far seas to catch fish. After living on the island, he got familiar with the surrounding situation bit by bit all by himself.

On August 15th, there are the most mackerel. In the past, on a big ship, the older generation took us to catch the mackerel. They took us to the place and told us where there were mackerel. When we live on the island, we catch them ourselves. From September to December, it is windy, and the weather is bad. You can only go to sea for four or five days a month.

Island fishermen's knowledge of the ecological environment of the South China Sea is not limited to islands, reefs and the sea. Their knowledge of the ocean and the surrounding world is three-dimensional and comprehensive. In particular, they know exactly the distribution and activity patterns of marine animals in different areas and depths:

They (all kinds of marine animals) will definitely go there when they swim up, and they will never change. This kind of fish will go up to the rocks, beautiful rocks, caves, and play. They don't go to the reef flats or the coral clusters. They have their habits. Like we live in Xisha, (when) we go out and (we) want to go to Beijing. Lobsters live in the cave during the day and come out at night.

The island fishermen observe the changes in weather and sea conditions at any time and decide where to go and what fish to catch the next day. Every fisherman has a good understanding of the sea production in the surrounding waters. In terms of specific operations, the old fishermen are more experienced, and the younger fishermen are better at physical and difficult tasks:

In the time of my dad's generation, there used to be a lot of fish. It's not the same in our generation. The reef flats have changed and we must have a knack for catching fish. Now anyone catching fish has his own way. When I see a fish, I usually won't let it run away. You have to have the strength to chase it and chase it all the way into the stone. It swims very fast. Which fisherman who goes out to sea has poor physical strength? What is it to come out to catch fish if you are not physically strong? If you pick up a basket of snails, you won't be able to get it on (the boat). If you go into the water and get a string bag of snails, you won't be able to get it on the boat by yourself.

The weather, island ecological environment and surrounding products of the South China Sea are constantly changing. Fishermen have developed a variety of fishing and hunting modes based on the situation, such as spearing, line fishing, fishing using eel cages, netting, snorkeling, and injecting oxygen. Each skill is a set of systematic knowledge, which is mastered by the continuous actions and 
movements of the fisher and hunter. Fishermen use a variety of simple tools to penetrate the surrounding waters in their own way. Regardless of the method, it is based on the fishermen's physical abilities such as eyesight, foot strength, and vigor. For this reason, the fishing and hunting styles of fishermen living on the islands reflects the most direct contact and interaction between humans and the ocean, and between humans and marine animals. The fishermen who live on the islands themselves have become a group with great action, personality and creativity. A real fisherman who lives on an island must be distinguished from other fishermen in thinking, habits, and physical fitness.

\section{Organization and cooperation of the fishermen communities on the islands}

The islands are far away from the mainland, and the sea route is dangerous and far away. Most of the people who live on the islands are a combination of fathers and sons and that of brothers. "On the Xisha Islands...the people living on the island are generally fishermen from Qiongdong County, Wenchang County, Hainan Island, with the most from Tanmen Port. But there are no women on Xisha Islands" (Han et al. 1988). The first members in a fisherman's family to go to the islands are usually two adult brothers or cousins. After creating basic living conditions on the island, they bring their grown-up sons. These boys are mostly 15 or 16 years old. Later, the people who go to the island extend to male relatives of both men and women and live on the chosen island in a manner of mutual assistance.

$F u$, who lives on the Yongxing Island in the Yongle Islands, is 55 years old and is from Wenchang, Hainan. In his early years, he followed his family to fish on a fishing boat, and later chose to live on the island:

I went to sea with my father when I was 18, and I first caught fish in the waters of Qinglan, near Wenchang. Later, I came to Xisha with a big boat from my uncle. I have been to Chenhang Island, Nanshazhou and Dongdao Island, and Dongsha as well. That was in 1987, we mainly fished for mackerel. The big boat was broken after too long of a time, so I stopped being on the boat. I saw people living in Yongxing, so I went to live on the island. I first lived on the island for two months, earning two month's money, and went back. People saw that I made so much money and came to Yongxing Island with me.

Zhaoshu Island in the Xuande Islands is one of the main fishermen's habitations in Xisha. The island has lush vegetation and good ecological conditions. The number of fishermen living on the island is second only to Yongxing Island. Many fishermen have lived on the island for decades. Fisherman Liang is from Moxiang Village, Tanmen. He is 40 years old this year and is already an old islander. He is familiar with every blade of grass and every tree on the island. Liang went to the Island with the elders of the same surname in the village when he was 14 years old and has lived on the island for more than 20 years. He spends more than two hundred and seventy days on the island every year. In that very year, he followed the 
elders in the village and floated on the sea in a wooden boat for 2 days and two nights. When they ventured to Zhaoshu Island, there were only a few simple houses on the island.

\section{"These houses were built by our fishermen predecessors."}

There were seven or eight households on the island at the time, but now there are dozens of fishermen households.

People here are all from one place and the earlier fishermen take relatives or fellow villagers out to sea. All of us just came here to make a living. Anyway, my family's ancestors have been fishing for generations. My dad, my brother, and my brother's children all came here to make a living.

Bloodline and geography are the organizational basis of the fishermen communities on the islands. The fishermen who live on the island take father-son and brother-brother as the basic unit, and then bring other male relatives, neighbors, friends, and "people from the same village" to live on the island. These distant or close relationships are also used for cooperation in daily residential activities and work.

Among the dozens of fishermen living on the Lingyang Reef of the Yongle Islands, most are Lintong fishermen from Tanmen, except for two or three families from other villages. More than half are members of the family with the surname Shi from Lintong. Xiao Shi, who went to the island earlier, said that at the earliest he and his cousins, altogether three men came to Lingyang Reef and picked snails here. Later, other relatives gradually came to live on the island and brought people from the same village. Lingyang Reef, in this way, has become a habitation of fishermen dominated by one village and one surname. The fishermen who live on the Yinyu Island, about 10 nautical miles away from the Lingyang Reef, mainly come from Caotang in Tanmen. Forty-eight-year-old fisherman Zhang talked about his experience of going to the island in his teenage years:

I graduated from junior high school and didn't want to study anymore. My home is two or three hundred meters from the sea, and I was very happy to catch fish with my friends. The two old men next door, who were related, took me to Xisha. I was fifteen or six years old, and that was in the 1980s. The old men who took me here are now already over 80 years old.

In the decades after this, his two brothers, and their younger generation, including his two son-in-laws, one after another, came to the Island. Now there are seven or eight members of his extended family on Yinyu.

The fishing group organizes livelihood activities mostly by blood. This is mainly because marine livelihoods are changeable and dangerous. Marine operations are life-threatening and family members are the most trustworthy. As far as housing is concerned, the most common is that father and son share a coral house, followed by brothers and cousins. Sometimes a fisherman lives with his partner 
who goes to sea together, for it is convenient for the work. Few people go to the islands alone. Whether it is to create living conditions or to fish for seafood, a fisherman needs to cooperate with others. There are some means of livelihood that can be done alone, such as picking up snails, spearing fish, fishing, and placing eel cages on the reef. Some operations must have a partner, such as catching fish with oxygen in the deep sea outside the reef flat at night. A dedicated person must drive a small boat to observe the oxygen pipe on the water surface and cooperate and respond with a high concentration of energy. Individuals who have no partners from their own nuclear family or relatives will ask close friends from the same village to go to the island together. Such close friends usually have already gone out to sea together in their hometowns and have similar tastes and interests. There is a geographical and ecological difference between the islands. Fishermen who choose to live on a certain island intend to catch a certain kind of seafood in the surrounding area, so they have common skills and topics. To go a step further, they have a common way of thinking or cultural logic to understand the world around them and produce common behaviors (Huang 2010). Every household on the island, whether it is based on blood or a group of like-minded people, is a social and economic unit integrated with residence, sharing a common life experience and forming a mutual-aid relationship of high trust with each other.

The kinship organizations and regional groups, again overlap with the age groups. The age of males who "Zhanzhi" ("Zhanzhi" means staying on an island for a long time.) in the South China Sea ranges from 15 to more than 50 years old, with most being between 35 and 55 years old. Compared with modern fisheries that rely on advanced technology, fishing and hunting livelihoods in the South China Sea islands and reefs that rely on simple tools require individuals to have flexible resilience and considerable physical strength. Young adults are more suitable for the South China Sea island and reef operations. A group formed after living on an island for a period of time has the right to use surrounding resources. Becoming a member of a group also means automatically forming a relationship of mutual assistance.

The fishing range of the fishermen on the island gradually extends from the reef flats around the island to the deep water area. It seems that the fishermen were endowed various and diverse ocean resources by the nature. Islands and atolls are the most abundant in the seafood in the ocean. The diverse geographical and ecological conditions of reefs, lagoons, harbors, sandbars, and deep seas enable the islanders to make a living by relying on their own skills and abilities. The fishermen on the islands are completely unrestrained, free and independent in their choice of working location, time, and working methods. This seemingly fragmented method of livelihood is based on the premise of people helping each other. In addition to family members who were already a production and living group when they came to the island, the cooperation and mutual assistance of long-term fishermen spans the range of relatives and exists among the fishermen on their islands and among the islanders of every island in this sea area.

As far as an island is concerned, fishermen of different ages are good at different skills, so various cooperation modes can be reached. In order to maximize the benefits, they must cooperate and compromise. The fisherman $L u$ of Yagong Island is good at 
diving and catching fish. Diving in the deep sea to catch fish requires someone to sail along. Sailors should observe the surface of the water, understand the trajectory of the fishermen about ten meters underwater, and drive the boat to keep up. Inexperience or a little carelessness can cause danger to underwater fishermen. The fisherman Lao Yu is over 60 years old and has no physical strength to dive and catch fish anymore. $L u$ asked him to help sail the boat and go out to sea together.

He helps me drive the boat and I dive in the deep sea. We go out to sea at around 6 o'clock in the afternoon, look for a good place before the sun set. I will not go into the water until it is all dark. Six or seven hours at sea, eight or nine times in the water, depending on the weather. It is almost 11 or 12 o'clock in the evening or 1 o'clock in the morning, when we go back to the island. I took $60 \%$ of the income, and he took $40 \%$.

They go to different sea areas every day. In the process of leaving the island and heading to the deep water, $L a o Y u$ and $L u$ observe all the changes in color of the water and changes in waves, constantly discuss and exchange opinions, and finally find a suitable place. Old $Y u$ finds the right type of work by relying on his own experience and ability to sail ships. $L u$ also learned the ability to observe the sky and the sea to judge the conditions of the seabed through cooperation with the elderly. On a small island with a small terrain and a limited number of people, the islanders understand everyone's experience and technical expertise. According to their respective circumstances, they are free to reach different methods of cooperation.

Mutual assistance between boats or fishermen living on the islands is necessary. In the unique, dangerous and uncertain environment of the ocean, people have reached an unwritten rule-mutual assistance. The fishermen abide by this principle. No matter how far or near the relationship is, or how big or small the difficulty is, the people who see should help. Whether it is material shortages in daily life, lack of spare parts for ships in production, or other ships or fishermen in distress at sea, the utmost assistance must be made. They share food and fresh water and respond promptly to each other's difficulties in work and life. In this way, a circle of mutual assistance is formed among certain groups of people. Everyone is a giver and everyone is a beneficiary. When someone leaves the island, they will help others by bringing back seafood to sell, and the people who come to the island will also help bring in supplies needed on the island. People are well aware of the value and importance of this rule. Living in solitary islands and reefs in the vast ocean, people can only depend on each other. Only by giving when others need help, can one get help when it is needed. This kind of return is delayed, but it ensures that one will not be in a situation of isolation and helplessness at any time.

In July 2018, a ship approached Zhaoshu Island, and the boatman went to the island to seek help from an islander. He was convinced that he could get help.

"I saved his life." 
Even though this happened at sea long ago, it is still apart of their long-term relationship. When the boatman went to the island, as usual, he took part of the ship's supplies, fruits, meat, and wine, and gave them to the islander he was looking for. He knew that the island lacked these supplies. This kind of mutual assistance and reciprocity is the survival strategy of the islanders who live and work on the offshore archipelago, and it is the basis for them to be able to live on the island for a long time. Based on this mutual assistance, the fishermen themselves also believe that:

"As people of the sea, we are pretty good."

Regardless of the size of the islands and reefs and the number of people living on the islands, there are brother temples built on coral rocks on all islands and the reefs of Xisha Islands. The old fishermen who live on the islands remember that decades ago, there were already temples on the islands, which were built by the ancestors of the fishermen from their hometowns. The small temples on the islands are vulnerable to wind and waves, and fishermen have to take turns to repair or reconstruct. As in their hometowns, the fishermen worship Xiong Di Gong, that is, one hundred and eight brothers (Wang 2017). When they leave the islands, whether it is a long voyage or a trip to their hometowns, they must bring back chicken, pork, fruit, etc. to worship the temples upon return. The time that fishermen go to and from the islands is not fixed. They worship at the temples according to the time they return to the islands. On the first day and the fifteenth day of the lunar new year, or during important festivals, the fishermen on the islands will worship at the temples collectively.

The carrying capacity of islands and reefs and the surrounding sea production are limited. As the number of fishermen on an island increases, the harvest of individual fishermen on the island will decrease. They will choose to leave and move to a new island to live. Fishermen's newly selected islands and reefs must have ecological conditions suitable for their fishing techniques, and the nearby seafood must also meet their production expectations. For this reason, most of the fishermen who stay in the South China Sea for a long time have experienced the process of "impermanence of habitation" and they have lived on various islands and reefs in this sea area, either short or long. It is precisely because the fishermen's livelihoods on islands and reefs are mobile hunting activities, they need to get to know and familiarize themselves with each surrounding island, reef and sandbar with hands-on practice, grasp the situation of the entire sea area, and make choices at any time.

\section{Conclusion}

The presentation of the life and production of contemporary island fishermen groups can promote our understanding of the overall picture of the fishery society in the entire South China Sea. The marine experience of the fishermen living on the islands and their knowledge of specific sea areas also contribute to the exploration of the South China Sea by other disciplines. For example, geological and climatic scientists will use fishing equipment from different periods to analyze changes in sea level. The social life of the fishermen living on the islands in the 
South China Sea also helps us understand the early fishery societies. As Brian Fagan pointed out, ancient fishing and hunting tools are not easy to preserve and are difficult to find in archaeological remains. The only way to restore and understand the fishing techniques of ancient sea-related people is to study anthropologically the traditional methods that exist in modern fishing societies (Fagan 2019).

Hainan fishermen have been engaged in fishery production on South China Sea islands since ancient times. From sailing to the emergence of motorboats, the South China Sea fishermen have experienced different seafaring eras. The process of fishermen putting their roots down in the South China Sea islands and reefs is a process of long-term interaction between the South China Sea fishermen and the ocean islands. The special geographical and ecological conditions of the islands and reefs have caused the island fishermen to form a fishing and hunting economy and social form in the South China Sea Islands that is different from the general fishery society. They have also become a unique member of the South China fishery community. The fishing and hunting livelihood of fishermen living on islands, in response to special environments, are the result of the uninterrupted marine practice of fishermen in the South China Sea for generations and reflect their special significance for the use of marine ecology to achieve sustainable development.

Acknowledgements Thanks to anonymous review experts for their valuable comments and suggestions, which provide important information and guidance for the improvement of this article. The author also thanks the editors of "Ethnic Studies" for their detailed opinions and guidance.

Author's contributions The author read and approved the final manuscript.

Funding This article is a phased achievement of the Ministry of Education's Humanities and Social Sciences Youth Fund Project "Innovation governance research on the South China Sea marine local knowledge embedded into the Sansha community construction under the background of the 'One Belt One Road"' (Project Approval Number:20YJC850009)

Availability of data and materials Not applicable.

\section{Declarations}

Ethics approval and consent to participate Not applicable.

Consent for publication Not applicable.

Competing interests The author declares that she has no competing interests.

Open Access This article is licensed under a Creative Commons Attribution 4.0 International License, which permits use, sharing, adaptation, distribution and reproduction in any medium or format, as long as you give appropriate credit to the original author(s) and the source, provide a link to the Creative Commons licence, and indicate if changes were made. The images or other third party material in this article are included in the article's Creative Commons licence, unless indicated otherwise in a credit line to the material. If material is not included in the article's Creative Commons licence and your intended use is not permitted by statutory regulation or exceeds the permitted use, you will need to obtain permission directly from the copyright holder. To view a copy of this licence, visit http:// creativecommons.org/licenses/by/4.0/. 


\section{References}

Bauman, Zygmunt. 2013. This Is Not A Diary (《此非日记》). Translated by Yudong Yang (杨喻东). Guilin: Lijiang Publishing House (漓江出版社).

Braudel, Fernand. 2014. Histoire et Civilizations (《文明史》). Translated by Shaomin Chang et al. (常绍民等). CITIC Press Corporation (中信出版社). Beijing: p. 285.

Chen, Lunjiong (陈伦昫), and Changfu, Li (李长傅). 1985. “Haiguo Wenjianlu Jiaozhu” (《海国闻见录校注》). Zhengzhou: Zhongzhou Ancient Books Publish (中州古籍出版社).

Chen, Tianxi (陈天锡), Ziyue, Zheng (郑资约), and Xiujing, Yang (杨秀靖). 2004. The compilation of the South China Sea Islands (《南海诸岛三种》). Haikou: Hainan Publishing House (海南出版社).

Fagan, Brian. 2019. Fishing: How the Sea Fed Civilization (《海洋文明史:渔业打造的世界》). Translated by Wenyuan Li (李文远). Beijing: New World Press (新世界出版社).

Han, Zhenhua (韩振华), Jinzhi, Lin (林金枝), and Fengbin, Wu (吴风斌). 1988. Compilation of Historical Materials of South China Sea Islands (《我国南海诸岛史料汇编》). Beijing: Oriental Publishing House(东方出版社).

Han, Zhenhua (韩振华). 1981. The Collection of Research on the History and Geography of the South China Sea Islands (《南海诸岛史地考证论集》). Beijing: Zhonghua Book Company (中华书局).

Huang, Yinggui (黄应贵). 2010. The Afterglow of the Setting Sun Entering the Deep Forest (《返景入深林》). Beijing: The Commercial Press (商务印书馆).

Ingold, Tim. 2000. The Perception of the Environment. London and New York: Routledge.

Ju, Jiwu (鞠继武). 1954. The South China Sea Islands of the Motherland (《祖国的南海诸岛》). Beijing: Knowledge Publishing House (知识出版社).

Kou, Junmin (寇俊敏), and Guoqiang, Li (李国强). 1990. “Forty Years of Pioneering Work -- Interview with Professor Han Zhenhua, a Scholar of South China Sea History and Geography” (《拓荒耕耘四十载——访 南海史地学者韩振华教授》). China's Borderland History and Geography Studies (《中国边疆实地研究 导报》)

Liao, Disheng (廖迪生), and Zhaohe, Zhang (张兆和). 2006. Tai $O$ (《大澳》). Hongkong: Shenghuo, Dushu, Xinzhi Joint Publishing Company (Hong Kong) (三联书店(香港)有限公司).

Lin, Jinzhi (林金枝). 1981. “The Long History of the Chinese People's Development of the Products of Xisha and Nansha” (《中国人民对西南沙物产开发的悠久历史》). Southeast Asian Affairs (《南洋问题研究》) 3:65-77.

Lin, Jinzhi (林金枝), and Fengbin, Wu (吴凤斌). 1988. Southern Frontier of the Motherland--Islands in the South China Sea (《祖国的南疆——南海诸岛》). Shanghai: Shanghai People’s Publishing House (上海人民出版社).

Liu, Li (刘莉). 2014. “Fishing Rights and Sea Rights: Historical Investigation and Practical Significance of Fishermen along the Coast of Hainan Island” (《渔权与海权:海南岛沿海渔民的历史考察与现实意 义》). Journal of Sun Yatsen University (Philosophy and Social Sciences Edition) (《中山大学学报(哲学 社会科学版)》) 54(3):141.

Liu, Nanwei (刘南威). 1994. “The Naming of the South China Sea Islands in Ancient China” (《中国古代对 南海诸岛的命名》). Geographical Sciences (《地理科学》) 14(2):101-108.

Liu, Nanwei (刘南威). 1996. Draft of Geographical Names of the South China Sea Islands (《中国南海诸岛 地名论稿》). Beijing: Science Press (科学出版社).

Sahlins, Marshall. 2003. The Island of History (《历史之岛》). Translated by Daju Lan (蓝达居). Shanghai: Shanghai People's Publishing House (上海人民出版社).

Wang, Hengjie (王恒杰). 1992. “Archaeological Investigation of the Xisha Islands” (《西沙群岛的考古调 查》). Archaeology (《考古》) 9:769-777.

Wang, Libing (王利兵). 2017. “The Mobile God: The Sea God Xiong Di Gong Belief of the Fishermen in the South China Sea” (《流动的神明:南海渔民的海神兄弟公信仰》). Journal of Sun Yat-sen University (Social Science Edition) (《中山大学学报》(社会科学版)) 57(6):142-152.

Wang, Songxing (王崧兴). 1967. "Guishan Island: A Study of the Society of the Han People's Fishing Village" (《龟山岛:汉人渔村社会之研究》). Taiwan: Institute of Ethnic Studies. (台湾: 中央研究院民族研究所》).

Wu, Fengbin (吴凤斌). 1985. “The Development and Management of the Nansha Islands by Chinese Fishermen since the Song and Yuan Dynasties” (《宋元以来我国渔民对南沙群岛的开发和经营》). The Journal of Chinese Social and Economic History (《中国社会经济史研究》) 1:34-42.

Yang, Fu (杨孚). 2009. “Yi Wu Zhi (An Account of Strange Things)” (《异物志》). Guangzhou: Guangdong Science and Technology Press (广东科技出版社). 
Yue, Shi (乐史). 2007. Tai Ping Huan Yu Ji (《太平寰宇记》). Edited by Wenchu Wang(王文楚). 157. Vol. 157. Beijing: Dongguan County(卷157《岭南道一・广州》“东莞县”条): Zhonghua Book Company(中华书局).

Zhao, Liang (赵亮), Zhengsheng, Zhang (张争胜), and Wenlong, Nan (南文龙). 2016. “Mr. Zeng Zhaoxuan’s Important Contributions to the Study of South China Sea Geography” (《曾昭璇先生对南海地理研究的重 要贡献》). Acta Geographica Sinica(《地理学报》), no. 3.

Zheng, Ziyue (郑资约). 1947. Geography of the South China Sea Islands (《南海诸岛地理志略》). Beijing: The Commercial Press (商务印书馆).

\section{Comments}

Publisher's Note Springer Nature remains neutral with regard to jurisdictional claims in published maps and institutional affiliations. 